\title{
Fascicular tachycardia in a child: striking features that improve emergency management
}

\author{
Rita Ataíde Silva 다, ${ }^{1}$ Odete Mingas, ${ }^{1}$ Duarte Martins 다, ${ }^{1}$ Francisco Bello Morgado²
}

${ }^{1}$ Paediatric Cardiology, Centro Hospitalar de Lisboa Ocidental EPE Hospital de Santa Cruz, Carnaxide, Lisboa, Portugal ${ }^{2}$ Cardiology, Centro Hospitalar de Lisboa Ocidental EPE Hospital de Santa Cruz, Carnaxide, Lisboa, Portugal

\section{Correspondence to}

Dr Rita Ataíde Silva;

ritataide@gmail.com

Accepted 1 October 2020

\section{DESCRIPTION}

Few data exist on the incidence of spontaneously occurring ventricular tachycardia (VT) in the paediatric population. VT is often an unexpected finding in patients with otherwise normal hearts. ${ }^{12}$ These arrhythmias have a wide range of clinical presentation, going from infrequent ectopy to incessant VT. ${ }^{3}$ Their early diagnosis is essential to prevent ventricular dysfunction. ${ }^{4}$

The authors present a 5-year-old child without previous medical episodes, admitted to a paediatric emergency department of a secondary hospital on the grounds of gastroenteritis symptoms with 24 hours of evolution. Physical examination revealed disproportional tachycardia despite absent fever or clinical signs of dehydration. Blood analysis was unremarkable, with normal ionic balance despite previous diarrhoea. The electrocardiogram (ECG) was misinterpreted as supraventricular tachycardia (SVT) with right bundle branch block (RBBB), although the heart rate was 165 beats/ min. A rapid bolus of adenosine was administered, yielding no apparent response.

The case was discussed with our tertiary paediatric cardiology department. On examination of the postadenosine ECG, ventriculoatrial (VA) dissociation was demonstrated, with the ventricular rate exceeding the atrial rate, confirming a diagnosis of VT. Prompt transferal was organised. First, the child had received an amiodarone infusion for a few hours till final diagnosis was apprehended, marginally taming heart rate but no rhythm changes. On arrival, a transthoracic echocardiogram revealed no structural cardiopathy and normal function. ECG reappreciation allowed easy VT diagnosis: wide-QRS tachycardia, VA dissociation with fusion and capture beats (figure 1), right bundle branch block pattern and left axis deviation.

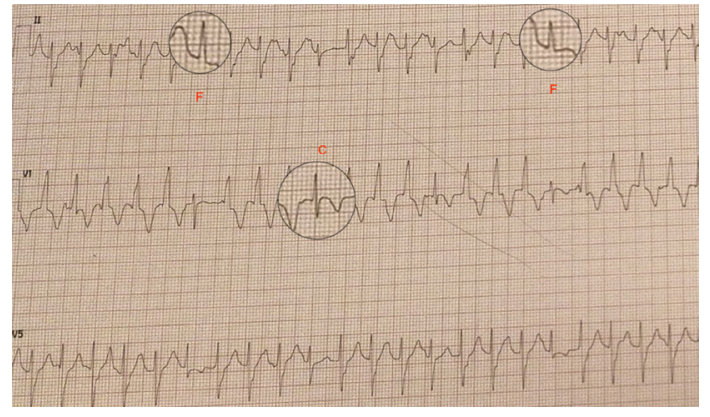

Figure 1 Fascicular tachycardia with typical findings: superior QRS axis deviation, atrioventricular dissociation with incomplete right bundle branch block; fusion $(F)$ and capture (C) beats.

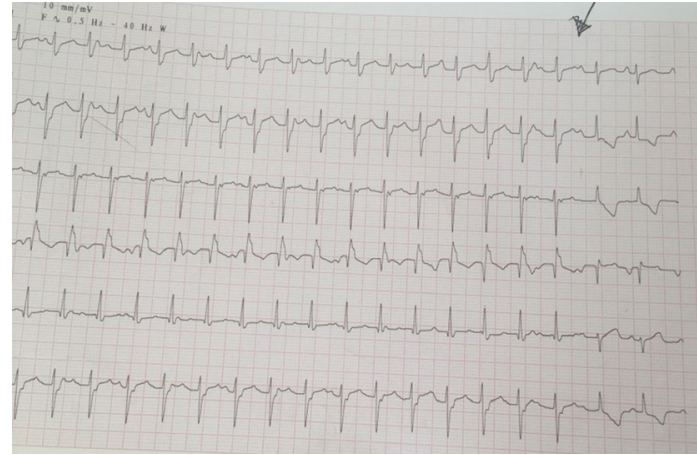

Figure 2 Reversion of tachycardia to sinus rhythm (arrow); heartbeat decreased from 145 beats/min to 95 beats/min abruptly.

After an accurate diagnosis, prompt consideration of calcium channel blockers use was made. Given that verapamil is known to have a negative inotropic effect and can cause sudden deterioration when given as a rapid intravenous push in infancy, we prepared a rescue dose of calcium gluconate and a slow timed push of intravenous verapamil was administered, registering ECG continuously. Sudden conversion to sinus rhythm was accomplished after $1.25 \mathrm{mg}$, and heart rate decreased from 145 beats/min to 95 beats/min abruptly (figure 2).

No haemodynamic repercussion was ever observed. The verapamil infusion was performed at our Paediatric Intensive Care Unit (PICU), with appropriate means of cardiopulmonary resuscitation. The patient remained in PICU and 7 hours after pharmacological conversion tachycardia recurred abruptly, exactly with the same characteristics. Successful reversion was achieved after the same dose of verapamil given by a slow infusion over 20-30 min as described by Kehr et al.

A few days later, with consistent sinus rhythm, the child was discharged with verapamil in the lowest recommended dose $(2 \mathrm{mg} / \mathrm{kg} /$ day $)$, subsequently

\section{Patient's perspective}

We realised that our child has had several periods of irritability that maybe could correspond to previous manifestations of tachycardia. Nevertheless, since they were intermittent and our child's development was uneventful, we did not pay much attention. Now we understand its importance and we are aware of its consequences. Gratefully, the medical team have made an accurate diagnostic before serious damages. 


\section{Learning points}

- Fascicular tachycardia is uncommon in children and can be falsely diagnosed as SVT when ventriculo-atrial dissociation, fusion and capture beats are not present. In most cases, there is a right bundle branch block type pattern with a superior axis.

- Clinicians must be aware of the main differences between supraventricular and ventricular tachycardia, keeping high suspicion levels when adenosine does not change heart rate. Recording ECG during its administration is crucial to make an accurate and prompt diagnosis so tailored treatment can be provided in order to avoid ventricular dysfunction. The prognosis generally is favourable.

- Although uncommonly used in paediatric age, verapamil can be safely used in certain situations, particularly after 12 months of age, but should be given slowly, over 20-30 min, rather than by intravenous bolus.

adjusted according to her weight progression. One more episode of tachycardia was documented associated with unadjusted weight dose. Follow-up echocardiograms revealed preserved ventricular function and 24-hour Holter monitoring showed no dysrhythmias. Home monitoring of heart rate (performed three times a week by her mother) showed controlled values (maximum heart rate of 105 beats/min). In the future, percutaneous ablation of tachycardia may be considered in case of relapse or refractoriness to therapy.

Contributors DM has received the child in PICU and collected all data supporting the diagnosis. FBM has helped to make accurate diagnosis and suggested treatment. OM and RAS had written the case and gathered literature. RAS is responsible for the child's medical follow up.

Funding The authors have not declared a specific grant for this research from any funding agency in the public, commercial or not-for-profit sectors.

Competing interests None declared.

Patient consent for publication Parental/guardian consent obtained.

Provenance and peer review Not commissioned; externally peer reviewed.

\section{ORCID iDs}

Rita Ataíde Silva http://orcid.org/0000-0002-2090-0984

Duarte Martins http://orcid.org/0000-0003-0662-5629

\section{REFERENCES}

1 Iwamoto M. Idiopathic ventricular tachycardia in children. Circ J 2011;75:544-5.

2 Roggen A, Pavlovic M, Pfammatter J-P. Frequency of spontaneous ventricular tachycardia in a pediatric population. Am J Cardiol 2008;101:852-4.

3 Belhassen B, Shapira I, Pelleg A, et al. Idiopathic recurrent sustained ventricular tachycardia responsive to verapamil: an ECG-electrophysiologic entity. Am Heart J 1984;108:1034-7.

4 Kehr J, Binfield A, Maxwell F, et al. Fascicular tachycardia in infancy and the use of verapamil: a case series and literature review. Arch Dis Child 2019;104:789-92.

Copyright 2020 BMJ Publishing Group. All rights reserved. For permission to reuse any of this content visit

https://www.bmj.com/company/products-services/rights-and-licensing/permissions/

BMJ Case Report Fellows may re-use this article for personal use and teaching without any further permission.

Become a Fellow of BMJ Case Reports today and you can:

- Submit as many cases as you like

- Enjoy fast sympathetic peer review and rapid publication of accepted articles

- Access all the published articles

- Re-use any of the published material for personal use and teaching without further permission

Customer Service

If you have any further queries about your subscription, please contact our customer services team on +44 (0) 2071111105 or via email at support@bmj.com.

Visit casereports.bmj.com for more articles like this and to become a Fellow 